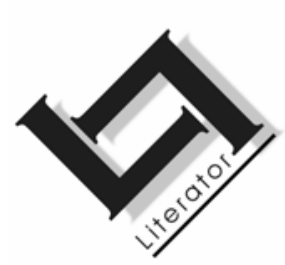

\title{
Let's sing our heroes: A comparison of biographical series for children in Kenya and South Africa
}

\author{
Colomba Kaburi Muriungi \\ Department of African Literature \\ University of the Witwatersrand \\ JOHANNESBURG \\ Email: muriunc@hse.pg.wits.ac.za
}

\section{Abstract \\ Let's sing our heroes: A comparison of biographical series for children in Kenya and South Africa}

In this article two series of biographies written for children, and dealing with prominent personalities in Kenya and South Africa, are compared. In the line of argumentation developed the aim is to examine the main features in these biographies, and to indicate the importance of biographies in the general field of children's literature. By examining a sample text from each series the specific ways in which the authors mould these personalities into heroes of their countries are scrutinised. Furthermore the way in which gender is represented in the two series is also examined and it is argued that both men and women form part of any country's gallery of heroes. Underlying the main argument of the article is the contention that biographies are important in perpetuating the stories of the two countries' heroes: also in teaching the history of each country to the young. A general motif of hard work resonates in these works, and therefore it is asserted that individuals' biographies can be used as anecdotes to communicate with and to inspire and encourage young readers. The authors of the biographies actually intervene by presenting children with role models. Furthermore these role models are not abstract fictional characters but real human beings who made great sacrifices for their countries people with whom children are thus able to identify. 


\section{Opsomming}

\section{Kom ons besing ons helde: 'n vergelyking van biografiese reekse vir} kinders van Kenia en Suid-Afrika

In hierdie artikel word twee reekse biografieë wat vir kinders bedoel is en wat handel oor prominente persoonlikhede in Kenia en Suid-Afrika, vergelyk. In die beredeneringslyn wat in die artikel gevolg word, is die doel om die belangrikste kenmerke van die biografieë te ondersoek en om die belangrikheid van biografieë binne die algemene veld van kinderliteratuur aan te toon. Deur 'n teks van elke reeks te ondersoek, word die spesifieke maniere nagegaan waarop die skrywers hierdie persoonlikhede vergestalt as hulle lande se volkshelde. Verder word ook nagegaan hoe geslag weergegee word in die twee reekse en word aangevoer dat sowel mans as vroue deel is van enige land se helde. Onderliggend aan die beredering hiervan word geïmpliseer dat biografieë belangrik is vir die uitbeelding van die verhale van albei lande se helde - belangrik ook vir die onderrig van elke land se geskiedenis aan die jeug. 'n Algemene motief van harde werk resoneer in hierdie reekse. Individuele biografieë kan dus aangewend word as anekdotes om te kommunikeer met, en om jeugdige lesers aan te moedig. Die skrywers van hierdie biografieë doen as 't ware iets ingrypends deur kinders as rolmodelle voor te hou. Verder is hierdie rolmodelle nie abstrakte en denkbeeldige karakters nie, maar regte mense, wat groot opofferings gemaak het vir hulle land - mense met wie kinders maklik kan identifiseer.

\section{Introduction}

Bethwell Ogot (2003:8-9) argues that if a country's heroes and heroines are forgotten, or if their contribution to their country's liberation struggle is not remembered after their death, then such heroes are condemned to a second death. They die a real first death and then a second death when their sacrifices and their heroism are shifted to the background and eventually forgotten. Ogot (2003) quotes David Macey to argue the case of Franz Fanon who was not recognised as one of the Algerian heroes after independence, despite his contribution to the fight for the Algerian liberation. Ogot indicates that according to Algerian nationalists, a black agnostic was not regarded a suitable hero for a Muslim state. Thus Fanon was not regarded as fit to be included in the official list of Algerian war heroes. This decision condemned him to a second death. However, it is not only Fanon that has been condemned to this second death. Many people who fought against the infiltration of colonialism in many African countries almost got completely forgotten after their countries had attained independence. 
In this article two series of heroic biographies for young readers are discussed - the one set in South Africa (Learning African History series) and the other in Kenya (Sasa Sema series). In this article it is argued that writing heroic biographies in any country is an attempt to save a country's heroes from dying the second death that Ogot (2003) refers to. The article examines the common features and differences in the two series of biographies, and further looks at how the authors of these texts mould their heroes. In addition, the article also examines how this representation may differ from previous heroic narratives - especially African oral narratives. The texts Chris Hani by Chris van Wyk (2003a) and Bildad Kaggia: Voice of the people by Evan Mwangi (2001) are sample texts to demonstrate how the heroes in these series of biographies are portrayed. It is argued that these biographies demonstrate that heroism is not an exclusively male phenomenon, and secondly, that the texts help children to understand and identify with their country's history. Towards the end of the discussion the importance of biographies in children's literature in the two countries is explained - with emphasis on the fact that biographies can provide children with role models.

Written African stories for children have been characterised by their reliance on traditional oral folktales. These folktales have been repeatedly included in books that children read as substitutes for fireside tales that were popular with their grandparents. Many of these stories contain heroic characters who are admired for their courage and wit. Many of these tales feature animal characters and the hare is invariably presented as a clever character that always emerges as a hero. For instance in Zawadi [a present], by David Maillu (1998), the hare saves Mapango, the protagonist, from the threat of being eaten by an ungrateful crocodile. In folktales where human beings are heroes, they turn out to be people mostly with disabilities who end up solving a problem that has defeated all the able-bodied men. For example, in Maillu's Mbengo and the Princess (1989), Mbengo, a thin, poor young man heals the king's daughter from her illness and thus gets the opportunity to marry the princess.

Although Africa has many political heroes and other kinds of cultural heroes such as sportsmen, such heroes have only recently been immortalised in written texts aimed at a young readership. The two series discussed in this article exemplify this concern with national archiving. Consequently, a major shift in characterisation is obvious. Whereas earlier children's narratives concentrated on animal characters and fictional youthful human characters, the texts committed to reframing national memory feature adult characters 
whose real life stories are traced from the onset of their childhood. In the process their heroic deeds are documented and presented as inspiring examples of reality for young readers to emulate. These changes in characterisation in children's stories we argue are "indications of more extensive and far-reaching changes ... taking place in the fabric and structure" (Campbell, 1996:35) of children's literature in Kenya and South Africa.

Biographies contain facts as their foundation, but for the purposes of this article they are read as fiction due to the fact that an imaginative dimension is required to integrate facts into a text. According to Schabert (1990:10), this imaginative dimension is provided by the act of writing. Nadel (1984:105) argues that although biographies may be viewed as fact, "fact alone cannot determine a life nor can it fashion a narrative, so every biography has elements of fiction". Quoting Pirandello, Nadel (1984) argues that facts are like a sock, which can not stand if empty. An imaginative dimension in combination with facts is thus needed in order to construct biographies.

\section{Major characteristics of Kenyan and South African children's biographies}

Reading through the biographies to be discussed in this article, we discover various differences and similarities. These differences and similarities can be attributed to either interrelated or diverse encounters in the history of the two countries. Disparity in writing can also surface, depending on the kind of information the authors prefer to foreground as part of the history to be passed on to children in each country. The majority of the Kenyan texts in the Sasa Sema series are about political heroes. In addition, a literary hero, a Mau Mau1 freedom fighter, a photographer and a religious leader feature - vocational range that shows that heroism is not confined to politics. According to Lila Luce (2003), the managing director of Sasa Sema Publications, many more biographies will be published to include athletes and people who have excelled in various other fields.

In the South African series all the heroes are freedom fighters, mainly those who played key roles in fighting apartheid. It is argued that the fight against apartheid is foregrounded in these texts due to

1 Mau Mau was a liberation struggle movement in Kenya in the 1950s. 
the fact that the young South African generation may not be familiar with the lived experience and trauma of the apartheid era. Privileging apartheid in these texts therefore helps children to understand what life was like for their parents and grandparents. Garson's views (2003) published in an online review, can be used as a point of departure to argue that using individuals as vehicles to describe South Africa's journey from apartheid to democracy, sustains the interest of the reader and allows him or her to identify with each of the individuals' story. At the same time the reader absorbs the historical context in which struggles were played out. Foregrounding individual stories, therefore, becomes an important tool in narrating the history of the nation.

While the Kenyan biographies in the Sasa Sema series are written by different authors, the South African biographies in the Learning African History series are all written by the same author. The South African biographies therefore tend to use a comparable style, with certain episodes repeated in different texts virtually in identical words. In the Kenyan biographies the different authors use a variety of styles that range from authorial narration to third-person narration, for instance a grandmother figure who narrates the story of the hero to the audience. Some authors go as far as using the folktale opening formula, "once upon time" and closing formula "and so it was for many days", that is typical of African oral narratives. For instance Elizabeth Mugi-Ndua, $(2000: 1,80)$ employs this technique in writing the story of Mekatilili, a Kenyan heroine.

Furthermore, while colourful real photographs are used as illustration in the South African texts, only drawings are used in the Kenyan texts. Whatever kind of representations, however, these illustrations have the power to enliven the story, therefore retaining the interest of a young readership (Georgiou, 1969:62). Not that illustrations give new information or expand on what is already known, but at least they add to the story by making it clearer for the readers (Glazer, 1997:42-43).

One of the ways in which these stories signal a young readership is through their use of simple language and the explanation of difficult words within the text. Explaining the meaning of words in children's books is not only an effective method of building vocabulary, but it also enables children to read coherently without having to hesitate when they encounter new words. In almost all the texts in the South African series the word apartheid is explained: 
In 1948 there was a general election. Only white people could vote and the National Party was elected. This party wanted black and white people to be separated. The new government was called apartheid (Van Wyk, 2003c:17).

The emphasised words, like apartheid above, are also explained in a glossary that is given at the end of the text. Many other words like demonstration, pass-book and trial, just to mention a few, are explained in a similar way. In addition, Van Wyk provides a list of important dates in the life of every personality, which include dates of birth, arrest, trial, and death - if the person is deceased. Although there is no glossary available in the Kenyan texts, many of the difficult words are explained in the text. For example in the quotation below the expression Second World War is explained (Mwangi, 2001:31):

The Second World War broke out in 1939 when Kaggia was seventeen. It is called world war because almost every country in the world was involved in some way.

The use of subtitles is another important feature common in both series and serves to introduce new ideas into the story and to provide a clear indication of stages in the hero's life. This device helps the young readers to grasp the story line easily. Each idea and/or expedition that a person undertakes is represented by a subtitle in the texts. In a way these subtitles summarise the story.

The two series also acknowledge non-black heroes as having contributed to the history of the two countries, either in the fight for independence or in other areas. In Kenya Mohammed Amin (see Nyutho, 2000) and Mulla Jeevanjee (see Patel, 2002), are seen as such heroes of Asian origin - Mohammed Amin being presented as a brave and an unwavering photo journalist. His heroism is revealed by the fact that he travelled to many war-torn areas like Uganda during Idi Amin's regime, and other perilous areas like Ethiopia and Somalia, to take photographs and collect stories, thereby keeping the world informed. This representation helps to carry the heroic narrative beyond political discourse and touches onto other areas of achievement. Helen Joseph, a white woman born in England, who migrated to India and later to South Africa, is celebrated in the South African series as having done a lot in the fight against apartheid. Thandile Nkomo, a Grade six pupil at Ferreira Primary School in Johannesburg expressed her admiration towards Helen Joseph for having helped blacks to fight for their freedom despite her being white (Nkomo, 2004). 
Another similar feature between the two series is the celebration of women's deeds in the fight against apartheid in South Africa, and against colonialism in Kenya. Such recognition helps in taking these narratives further in revising the notion of heroism, which has repeatedly been viewed as a male phenomenon within many African cultures (Pearson \& Pope, 1981:vii), and more especially in liberation discourses. Mwana Kupona (see King'ei, 2000) and Mekatilili wa Menza exemplify this female heroism in Kenya. In Mekatilili, Mugi-Ndua (2000:61-62), presents Mekatilili as a woman who fought colonialism in Kenya vigorously. At one point she was detained at Kisii prison in Western Kenya, but she escaped from jail and walked all the way to her home in the coastal region to continue with the fight. In South Africa we have the stories of Winnie Mandela and Helen Joseph who fought apartheid alongside men. This recognition of women (Van Wyk, 2003b; Van Wyk, 2003d) provides young girls with alternative views of womanhood so that they are able to realise that they should not necessarily be confined to the kitchen, to certain jobs and "safe professions" like elementary teaching and nursing. This gender reconstruction is also important because it nurtures boys into realising the potential of women and appreciating the fact that their female counterparts are not an inferior class. In an article published online in a Kenyan newspaper Sunday Nation, Ali Mazrui (2000) notes that most of the unsung super-heroes of the twentieth century struggle against white minority rule in Africa, are women who took great risks in this struggle. He cites Winnie Mandela as one of these unsung super-heroes. Mazrui points out that Winnie Mandela was harassed, banned, detained and humiliated. He reiterates that despite this mistreatment, Winnie kept the flame of the struggle alive. Yet her heroism was often celebrated more abroad than in her own country. But today, seeing her biography in the Learning African History series, one can rightly write back to Mazrui and tell him that in the twenty first century, the song for such un-sung heroes is under way.

In Learning African History series and the Sasa Sema series, characters are infused with qualities of courage, determination, perseverance and willpower that make them succeed in their tasks. All these characters are portrayed as heroes in their own areas in which they endeavour to work. In these texts characters are seen to occasionally suffer from doubt, dilemmas and setbacks, while other times they succeed in overcoming setbacks like these. We therefore learn that these personalities become heroes not because they are superhuman but by acquiring certain characteristics that aid to their success. Such representations help the young to understand life as 
a process of learning where one can make mistakes, but by acquiring a kind of purpose in life and determination, one can succeed in various future avenues.

\subsection{The making of the hero}

This section of the article focuses on how the authors portray their heroes. The biography of Chris Hani by Chris van Wyk (2003a) is analysed as a representative of South African texts, while the biography of Bildad Kaggia by Evan Mwangi (2001) represents Kenyan texts.

\subsubsection{Chris Hani}

Van Wyk (2003a) shows us that Chris Hani grew up as an ordinary village boy, but that he was respectful and hard-working. "Everyday he collected firewood and fetched water from a stream, far away from home" (p. 7). Consequently, other boys teased Hani for doing tasks that were thought to be women's jobs. However, Hani did not get angry for he knew "he was helping his mother" (p. 7). Hani's willingness to perform "women's jobs" serves to question gender bias and division of labour. Through a text like this, children can be assisted to change some attitudes, especially towards the performance of certain duties which are deemed "women's only" or "men's only". From a mere boy fetching water in the village, Hani rose to a great soldier, who fought against apartheid and thus he became a hero of his country. Through his story a reader learns that one does not have to be born great to reach higher horizons. Hani's determination to succeed in life communicates the idea that a hero is self-made, because if motivation does not come from within, then success may not come easily. Writing a person's life story starting from his childhood as the two series do, enables children to realise that heroes were once children and that they are ordinary people who may even come from very poor and humble homes (Tutu, 1997:iv).

Hani's heroism is shown to have been apparent early in his life: "He was a quick learner and always came first in his class ... He was so clever that he completed two grades in one year, twice during his school career" (p. 9), and graduated from university when he was only nineteen years old (p. 17). Throughout the text the author emphasises Hani's important qualities that trigger readers' admiration for him. He is also presented as a very daring person. Hani joined the ANC youth league at the age of fifteen while at Lovedale School and he influenced other youths to join too. Despite 
the illegality of political activities in black schools at that time, the author emphasises that Hani led other students in making ANC posters and putting them up in the school at night (p. 13). Leading others here foregrounds the character's heroism. Hani was so determined to fight apartheid that he even opted not to participate in sport because "he believed there were more important things to do when black people were not free in their own country" (p. 13). Such determination helps to show that uprooting the apartheid system in South Africa was not easy, but that it succeeded because of commitment and purpose to take action by characters like Hani and others.

The author shows us that Hani's determination to fight against the apartheid system did not end at school. When he left school he joined military training overseas in 1962 to build the ANC army: "This army was called Umkhonto we Sizwe, which means 'spear of the nation'. It was also known as MK for short" (p. 19). The narrator informs us thus:

... Hani slipped out of the country to begin a dangerous life as a soldier. He first went to train in Russia where he learnt to use guns and bombs. Then he went to Tanzania to help build an MK camp in the bush there (p. 19).

... and Hani spent 20 years in the bush working with the ANC army to fight apartheid from outside the country (p. 23).

These quotations illustrates how people were willing to sacrifice their time and risk their lives for the sake of their country. The motif of hard work and determination that the author adopts helps to expose the heroic attributes of Hani. This text contains photographs that show both men and women MK soldiers in their training bases in Tanzania (p. 18) and in Uganda (p. 20). Having both men and women participating in the MK army, again refutes the gender bias mentioned earlier. Also, the fact that MK soldiers operated from bases in other African countries demonstrates how these countries were in solidarity with South Africa's struggle against apartheid, thus taking the struggle narrative beyond South Africa to these other African countries.

Unfortunately Hani did not live long enough to enjoy the freedom he had fought for, as he was shot next to his home after he had returned to South Africa in the 1990s. The author notes that although Hani is dead, many people will always remember him "as the bravest soldier South Africa has ever had" (p. 27). His heroism as has been indicated - is portrayed by his selflessness and 
willingness to fight for freedom for the black race despite the hardship he encountered. Hani's death explains that heroes are not superhuman because they cannot evade inevitable phenomena like death. However, their heroic deeds remain unforgettable. The Learning African History series is thus keeping the national memory alive in South Africa by building an archive of biographies.

In Hani's biography and in those of other personalities compiled by Van Wyk, we notice the weaving together of events in a person's life and events within a certain country, a device also utilised in the Kenyan biographies. This intertwining of individual narrative with that of the nation, presents children's literature as one of the discourses through which a nation's history can be narrated and its future shaped. These biographies therefore perpetuate the story of the nation and also serve to keep the fire of our heroes alive. Like in South Africa, stories of people who contributed to the liberation of Kenya from colonial rule are being revived in the Sasa Sema series. One such person is Bildad Kaggia.

\subsubsection{Bildad Kaggia}

Evan Mwangi's biography (2001) on the life of Bildad Kaggia is an attempt to tell a story that may be at risk of being forgotten. Apart from his autobiography, The Roots of Freedom (1975), and a brief mention of Kaggia in Kenyan Secondary School history textbooks, his story is one that many young readers in Kenya may not be familiar with.

Like the history of Hani, Kaggia grew up in the countryside where he herded cattle, a background that again tells young readers that heroes are not really extraordinary and that a humble beginning is not an impediment to success. The author presents Kaggia as an inquisitive character from a tender age. This inquisitive nature earned him the name Kaggia, whereas his childhood name was Kariuki. This information comes to the fore in the text itself when one elder tells Kariuki: "A person who disturbs people with endless questions is nothing but a Kagia" (p. 7). Whenever the elders saw Kariuki, we are told, they greeted him as Kagia, because they thought he asked too many questions. Children also started calling him Kagia (p. 8). After some time Kariuki began to like the name and changed the spelling to "Kaggia". He used this name at school and it has survived up to today.

Many blacks in Kenya worked as squatters on settler farms during the time of Kaggia's youth. The settlers - we are shown - were, 
however, not kind to the squatters. Kaggia for instance once heard his father and other elders discuss how a white man slapped a black man after he had failed to go to work, and in amazement Kaggia asked: "Tell me, what are you doing about the Muthungu, the white man, who goes around beating people who don't want to work on his farm?" (p. 5). Asked what he would do, Kaggia said, "I would organize every one to chase white people out of this country ... We should fight them. This is not their country" (p. 5). Such reasoning from a small boy portrays his astuteness. In the portrayal of this incident, Mwangi represents childhood not as a time of sheer innocence, but as a time that for the likes of Kaggia is presented as real active subject of history, therefore highlighting that issues of freedom and history are also children's issues. It is important to note that in Bildad Kaggia Mwangi inserts a variety of fictive and everyday episodes taking place around the home, like cooking and beer drinking. It is at the beer drinking party that Kaggia heard the conversation about the ills of colonialism. These episodes, one would argue, add variety to the text instead of presenting the invasion and the ills of colonialism as plain hard facts - which could easily become boring - especially to a young audience.

Mwangi moulds Kaggia as a boy who grew up determined to excel at everything. At school he worked hard to avoid embarrassment, because poor students were given names to indicate their stupidity. $\mathrm{He}$ "worked so hard and became the best pupil. He was given the name Prince of Wales which was a great honour in those days" (p. 13; emphasis in the original text). Even other students marvelled at Kaggia's intelligence, as some said he was a genius, while others thought he was "on special diet" (p. 15). The author uses hyperbole here to demonstrate the character's achievements, thus presenting him as a hero in the eyes of the readers. At school we witness Kaggia's resolve to fight colonialism by his declaration that he wanted to become a warrior - not to raid cattle and goats but a warrior who would "send white people back to where they came from" (p. 14). Kaggia's later involvement in the Second World War and in the Mau Mau movement in Kenya therefore becomes a realisation of his childhood dream of becoming a soldier.

During the Second World War Kaggia travelled to many places, including Jerusalem and Britain, before returning to Kenya. Although all this time he worked as a British soldier, he gained enough experience on how to fight colonialism in his own country. Kaggia and other soldiers who fought in the Second World War returned to Kenya, burning with determination to free the country from 
colonialism. These people "had been accepted as Africans in other countries and they therefore could no longer accept to be treated as inferior to the whites. And they could not accept the oppression by the British government in their own country" (p. 69). Travelling abroad therefore acted as a source of inspiration to many freedom fighters in Kenya.

Like apartheid in South Africa, Kenyan citizens were divided by race. Blacks were therefore not expected to trespass in European or Asian areas. Kaggia, however, did not accept these conditions imposed by the British colonial government in Kenya, and together with others used to visit these forbidden places. Once he was arrested for having trespassed in an Asian residence at night. In the portrayal of this scene, Mwangi describes Kaggia's boldness in a way that makes him an unfaltering hero. During the prosecution Kaggia declared: "I do not recognize the law ... It is unjust" (p. 7677). He even stated he had trespassed willingly. In fact he refused to pay a fine imposed on him and claimed he was not willing to pay a fine for a law he did not accept (p. 77). Kaggia was consequently released without payment of any fine, and later the disputed law was repealed; a small victory "achieved by the use of peaceful disobedience" (p. 78), as Mwangi puts it.

Owing to his involvement in the Mau Mau movement and other organisations that sought independence from colonialism, Kaggia got arrested together with other Kenyan freedom fighters, like Jomo Kenyatta, Kenya's first president, when a state of emergency was declared in Kenya in 1952. The author indicates that the colonial government tried to hoodwink Kaggia into accepting to work for the British government so that he could be released. In a patriotic stand Kaggia, however, declared: "I cannot do that ... I haven't asked you to release me" (p. 87). Kaggia's refusal to cooperate with the British government points to the determination Africans in Kenya had in their struggle against colonialism. Persevering a jail sentence for the sake of people's freedom, can also be read as a heroic undertaking.

Kaggia's determination to fight injustice did not end with Kenya's independence in 1963. Mwangi shows us that Kaggia was not pleased with the way in which Africans who had lost land, failed to repossess their land after independence. Land went into the hands of people who had not lost any land, an issue that Kaggia questioned. He continued fighting against this injustice by the independent Kenyan government and he ended up in jail for a second time (p. 96), after which he resigned from politics and started his own businesses. Kaggia's jail terms demonstrates that struggle 
heroes did not always succeed by means of their endeavours. Obstacles like jail terms emphasise the fact that a hero can sometimes fail, in contrast to the portrayal of an all-perfect heroic character represented in most African heroic fictional narratives.

In Kaggia's biography we are presented with a personality who is determined to fight for a particular cause. One could argue that Kaggia is an inspiring factor especially to young readers, because throughout the story he fights for the common good of all people. He not only fights to free his people from colonialism, but he also does not want these people to suffer after colonialism will be over. Such a spirit of determination teaches the youth the purpose of being firm in one's decision, thus learning by example.

\section{The importance of heroic biographies in children's literature in Kenya and South Africa}

Karin Barber (1989:2) posits that what texts say is inseparable from history - in the sense of the past, because "texts are produced in specific historical circumstances the imprint of which they bear upon them" [emphasis added]. I find Barber's assertion that texts are produced in specific historical circumstances important for this discussion, because there has been a significant absence of literary books for children about famous people and heroes in African literature in general. Trends in children's literature in Kenya and South Africa are thus perhaps changing, because biographies about African political heroes, written for young readers, are a novelty in African children's literature. In this case writing such texts brings variety to this genre of literature. Many children's books in Africa tend to follow the familiar trajectory of having mostly young characters and animal characters, who are mainly used in fairly didactic terms as lessons concerning the kind of behaviour to emulate. Such a trajectory is not necessarily wrong, but by writing biographies about prominent figures in both Kenya and South Africa, the authors make an intervention by creating new models for children's literature. Biographies for children take children's literature beyond fantasy and moralising to address issues relating to history and politics. The supposition is that while remaining deeply concerned with issues of moral behaviour, these texts do not accomplish moral engagement through intangible ethical concepts, but through identifiable personalities who have left marks on African soil. Children are not only introduced to issues of morality and good conduct, but also to aspects of their national history that they must confront and engage with. Joan Glazer (1997:452) argues that 
biographies bridge what children "already know and understand with what they need - and even want - to learn". Biographies also provide children with "what has, and thus can be, accomplished by men and women" (Ernst 1997:71), which then acts as a source of motivation to children.

Biographies written for children are especially important, because they provide children with an ability to witness history-in-the-making through the experiences of an actual participant, whose personality and talent contributed towards influencing and changing the world and time in which he/she lived (Georgiou, 1969:417). By reading biographies a child becomes familiar with the kind of people who have shaped his/her nation and the world. Such texts are important because, as Donelson and Nilsen (1980:283) suggest, today's children are no longer admiring giants in folktales, but rather prominent people of whose existence or performance they know musicians and actors, or other powerful persons. As Marshall (1982:16) has argued, children no longer live a sheltered life common to earlier generations where stories could be told communally.

Comparative research on biographies written for children is also important, because this helps uncover some marginalised historical figures (especially in the case of Kenya), and popularise them through literature. The authors of these texts therefore act as storytellers to the new generation, because their texts tell stories of heroic deeds of personalities of the past (and present), and thus perpetuate the names of these people. As Achebe (2001:119) reminds us in Anthills of the Savannah, "it is only the story that can continue beyond the war and the warrior. ... the story outlives the sound of war-drums and the exploits of [a] brave fighter".

These biographies also help to provide a more complete portrait of personalities (heroes) that children can identify with, because biographies add variety to the portrayal of heroic figures. In the biographies discussed in this article, the image of the hero partly differs from those of previous children's writing, because the characters presented are real human beings as opposed to fictional characters. The representation of a hero has also shifted from an allperfect, semi-godly person/character, to one that has both weaknesses and strengths; someone doing well in some instances, while in other instances the character may struggle, make mistakes or even fail (Georgiou, 1969:418). This is shown by the fact that some of the heroes land up in jail in the process of fighting for freedom. These characters, however, rise again and continue with 
the struggle after they have been released from jail (for example Bildad Kaggia). This portrayal of the hero helps to show the young that heroes can sometimes fall but their heroism can be maintained through fortitude. Biographies thus "give children a pattern of reality from which they can draw elements to inspire and comfort them when they experience disappointment or some temporal failure" (Georgiou, 1969:48).

Garson (2003) feels that some aspects in the heroes' lives have been omitted in the South African series, thus treating these heroes as flawless individuals which make them seem less real. Garson's viewpoint may be partially true, but it is important to note that Van Wyk (2003a; 2003b; 2003c) emphasises some instances where his heroes encounter obstacles in their lives. Again, it may be that the author opts to avoid certain details in an attempt to shorten the texts for the readers. In fact, Van Wyk narrates the stories without burdening children with unnecessary details that might hinder the young minds from understanding. Omission of certain details can in no way be taken for a failure, because any writing involves a kind of selective remembering. What, however, remains important is whether the significant events are mentioned. Again, as Glazer $(1997: 443)$ argues, biographies are not required to relate every known fact about a subject from birth to death. A biography may instead focus on a few years of the subject's life or concentrate on particular aspects.

\section{Conclusion}

In this article it was attempted to indicate that biographies written for children in South Africa and Kenya reveal certain similarities and differences. It was argued that these texts present variety to the way in which heroic figures were presented in earlier heroic narratives, because they deal with real human heroes rather than with fictional characters. The line of argumentation has also hinted that heroism in any nation's liberation struggle is not streamlined and unflawed in the male figure. Women too have been heroes and they have played an important part in the liberation struggle of their nations. An examination of sample texts has helped to demonstrate how authors in both countries portray their heroes. The texts in the two series use children's literature not just as an avenue for recapitulating individuals' stories, but also as a channel through which children can learn many aspects of their country. The texts are important because they provide spaces for children not only to learn their history in a more simplified manner, but also in a more interesting 
way. The two series of biographies act as channels through which our passed-away heroes can come back to life through literature. They are therefore avenues through which we can re-sing and sing our sung and unsung heroes.

\section{List of references}

ACHEBE, C. 2001. Anthills of the savannah. London: Penguin.

BARBER, K. 1989. Discourse and its disguises: The interpretation of African oral texts. Birmingham: University of Birmingham.

CAMPBELL, J. 1996. Heroes and heroines in Soviet children's literature of the 1980s. (In Machet, M., Olën, S. \& Van der Walt, T., eds. Other worlds, other lives: Children's literature experiences. Proceedings of the International Conference on Children's Literature, 4-6 April 1995. Pretoria: University of South Africa. p. 32-54.)

DONELSON, K.L. \& NILSEN, A.P. 1980. Literature for today's young adults. Glenview: Scott.

ERNST, S.B. 1997. Gender issues in books for children. (In Lehr, S., ed. Battling dragons: Issues and controversy in children's literature. Portsmouth: Heinemann. p. 66-78.)

GARSON, P. 2003. Struggle heroes for children. http://www.southafrica.info/ ess_info/sa_glance/history/historybooks.htm [23 September 2004].

GEORGIOU, C. 1969. Children and their literature. Englewood Cliffs: PrenticeHall.

GLAZER, J. 1997. Introduction to children's literature. (2nd ed.) Saddle River: Merrill.

KAGGIA, B. 1975. Roots of freedom 1921-1963: The autobiography of Bildad Kaggia. Nairobi: EAPH.

KING'EI, K. 2000. Mwana Kupona: Poetess from Lamu. Nairobi: Sasa Sema.

LUCE, L. 2003. Interview. Nairobi, Kenya. Dec., 4.

MAILLU, D. 1989. Mbengo and the princess. Nairobi: Maillu.

MAILLU, D. 1998. Zawadi. Nairobi: Jomo Kenyatta Foundation.

MARSHALL, M.R. 1982. An introduction to the world of children's books. Aldershot:Gower.

MAZRUI, A. 2000. Why Africa has so few heroines. Daily Nation: March 5. http://www.nationaudio.com/News/DailyNation/05032000/Features/Newsa n ysis61.html [22 August 2003].

MUGI-NDUA, E. 2000. Mekatili wa Menza: A woman warrior. Nairobi: Sasa Sema.

MWANGI, E. 2001. Bildad Kaggia: Voice of the people. Nairobi: Sasa Sema.

NADEL, I.B. 1984. Biography: Fiction, fact and form. London: Macmillan.

NKOMO, T. 2004. Conversation between C.K. Mwrungi and T. Nkomo. Public Library, Johannesburg. 16 April.

NYUTHO, E. 2000. Mohammed Amin: The eyes of Africa. Nairobi: Sasa Sema.

OGOT, B.A. 2003. Mau Mau and nationhood: The untold story. (In Odhiambo, E.S. A. \& Lonsdale, J., eds. Mau Mau and nationhood: Arms, authority and narration. James Currey: Ohio University Press. p. 8-37.)

PATEL, Z. 2002. Mulla Jeevanjee: Rebel of the empire. Nairobi: Sasa Sema.

PEARSON, C. \& POPE, K. 1981. The female hero in American and British literature. New York: Bowker. 
SCHABERT, I. 1990. In quest of the other person: Fiction as biography. Tubingen: Francke.

TUTU, D. 1997. Forward. (In Maxim, L.J. Madiba: The rainbow man. Cape Town: National Book. p. iv.)

VAN WYK, C. 2003a. Chris Hani. Gallo Manor: Awareness Publishing.

VAN WYK, C. 2003b. Helen Joseph. Gallo Manor: Awareness Publishing.

VAN WYK, C. 2003c. Nelson Mandela. Gallo Manor: Awareness Publishing.

VAN WYK, C. 2003d. Winnie Madikizela Mandela. Gallo Manor: Awareness Publishing.

\section{Key concepts:}

biography as literary genre

history of the nation - the representation of national heroes - Kenyan and South African role models for children: hero figures

\section{Kernbegrippe:}

biografie as letterkundige genre geskiedenis van 'n nasie - die weergee van nasionale helde - in Kenia en Suid-Afrika rolmodelle vir kinders: heldefigure 
